\title{
PENGEMBANGAN GALUR KACANG TANAH UNGGUL (TOLERAN KEKERINGAN DAN NAUNGAN) DI LAHAN KERINGDESA KWANGKO KABUPATEN DOMPU
}

\author{
A. Farid Hemon, Sumarjan, Baiq Erna Listiana, Kisman, Lestari Ujianto
}

\author{
Kelompok Peneliti Bidang Ilmu Pengelolaan Sumberdaya Genetik \\ Tanaman Kacang-kacangan \& Hortikultura, Fakultas Pertanian, \\ Universitas Mataram, Mataram, Indonesia
}

Alamat korespondensi: faridhemon_1963@yahoo.com

\begin{abstract}
ABSTRAK
Varietas unggul merupakan komponen penting dalam usaha tani untuk peningkatan produktivitas kacang tanah. Kegiatan ini bertujuan untuk membantu kelompok tani mitra "Nanga Nae Dua" di Desa Kwangko untuk meningkatkan pengetahuan dan keterampilan petani dalam upaya meningkatkan produktivitas kacang tanah dengan penggunaan galur kacang tanah unggul (toleran kekeringan dan toleran naungan) dan produksi benih bermutu. Untuk mencapai tujuan tersebut, telah dilakukan kegiatan penerapan ilmu dan teknologi, dengan tahapan, yaitu: 1) diseminasi varietas unggul kacang tanah, 2) ceramah produksi benih bermutu dan penangkar benih, serta 3) demonstrasi plot budidaya galur unggul kacang tanah. Metode yang digunakan dalam kegiatan ini adalah metode pendidikan orang dewasa (POD) dengan teknik partisipatif. Kegiatan diseminasi dilakukan dengan sistem ceramah dan diskusi antara Tim Penyuluh dengan anggota Kelompok Tani. Kegiatan demonstrasi plot dilakukan dengan melibatkan petani secara langsung dalam merencanakan, menanam, memelihara, membandingkan, dan mengevaluasi pelaksanaan program pengabdian dilaksanakan. Hasil kegiatan menunjukkan bahwa petani sangat respon terhadap kegiatan pengembangan galur kacang tanah unggul toleran kekeringan dan naungan. Proses transformasi teknologi penggunaan varietas unggul dan produksi benih berkualitas kacang tanah telah terjadi pada petani. Petani juga mampu menggunakan benih bermutu untuk budidaya kacang tanah di lahan kering Desa Kwangko. Petani dapat membandingkan hasil demonstrasi plot antara benih dari galur unggul dengan benih asalan dari petani. Penggunaan galur unggul kacang tanah dari benih bermutu mampu meningkatkan produksi kacang tanah 2,5-3,3 ton ha-1polong kering atau meningkat sebesar 48-60,6\% dibanding dari benih asalan petani (1,3 ton ha-1) polong kering.
\end{abstract}

Kata kunci: kelompok tani, partisipasi, varietas unggul

\section{PENDAHULUAN}

Penanaman kacang tanah sebagian besar (70-80\%) dilakukan di lahan kering. Pengembangan kacang tanah di lahan kering sering mendapat masalah karena tanaman mendapat cekaman kekeringan sehingga menyebabkan produksi polong terhambat dan bahkan gagal panen. Pengembangan kacang tanah di lahan sawah beririgasi menjadi sulit karena harus bersaing dengan tanaman pangan lain yang lebih ekonomis seperti padi, jagung dan kedelai (Adisarwanto, 2008).

Desa Kwangko Kecamatan Manggelewa adalah salah satu daerah pengembangan kacang tanah di Kabupaten Dompu. Pengusahaan kacang tanah di desa Kwangko dilakukan pada lahan tadah hujan dan tegalan dengan kondisi air yang sangat terbatas (lahan kering) dengan modal dan keterampilan petani yang rendah. Petani disini menanam kacang tanah secara turun temurun. Harga jual kacang tanah sangat rendah karena kualitas kacang tanah sangat rendah. Kacang tanah yang dihasilkan biasanya kurang bernas, pengisian polong kurang penuh, dan polong banyak yang kisut karena tingkat kemasakan tidak serentak (Survei awal, Maret 2020).

Desa Kwangko adalah salah satu desa yang berada di Kecamatan Manggelewa. Kecamatan ini mempunyai luas wilayah 176,49 km2 dengan jumlah penduduk tahun 2017 tercatat 31.045 jiwa terdiri dari laki-laki 15.697 jiwa dan perempuan 15.348 jiwa, dengan laju pertumbuhan penduduk sebesar $1,46 \%$. Mata pencaharian penduduk sebagian besar ( $85 \%$ ) adalah bertani pada lahan kering dengan luas lahan rata-rata $0,75-2,0$ Ha. Bentuk lahan berbukit-bukit dengan jenis tanah kompleks 
Litosal mediteran coklat, kompleks Renzina dan Litosal. Luas wilayah desa Kwangko 23,83 km2 dengan jumlah penduduk 2.202 jiwa. Kondisi lahannya adalah lahan kering dan beriklim kering dengan suhu harian siang hari 30-350C, ketinggian tempat $2 \mathrm{~m}$ dpl, dengan curah hujan $85 \mathrm{~mm}$ dengan hari hujan rata-rata 7 hari tiap bulannya (BPS Dompu, 2018).

Penanaman kacang tanah di desa Kwangko biasanya dilakukan pada musim tanam II setelah penanaman padi. Penanaman setelah tanaman padi diharapkan untuk mendapatkan sisa air tanah untuk pertumbuhan tanaman palawija termasuk tanaman kacang tanah.

Penanaman kacang tanah di lahan kering sering mengalami hambatan karena ketersediaan air tanah yang sangat terbatas dan rendahnya penerapan teknologi usaha tani. Hasil pengamatan awal menunjukkan bahwa rata-rata produksi kacang tanah adalah sekitar $\pm 0,9-1,1$ ton polong kering dan masih sangat rendah dari produksi nasional 3-4 ton polong kering. Produksi yang rendah menyebabkan pendapatan petani kacang tanah menjadi rendah (Adisarwanto, 2008).

Kendala teknis penyebab rendahnya produktivitas kacang tanah, yaitu penggunaan varietas atau benih yang tidak memenuhi standar sertifikasi benih (Hidayat et al., 1999). Benih yang ditanam berasal dari benih asalan yaitu benih yang diperoleh secara turun temurun oleh petani, sehingga kemungkinan telah terjadi pengotoran benih melalui percampuran dengan varietas lain, persilangan alami, dan mutasi.

Ketersediaan benih kacang tanah merupakan kunci keberhasilan peningkatan produksi kacang tanah. Pemerintah Indonesia belum memprogramkan kacang tanah sebagai program intensifikasi nasional, sehingga ketersediaan benih bermutu masih kurang dan kadang tidak sesuai dengan standar sertifikasi benih. Kebutuhan benih kacang tanah selama ini berasal dari produksi petani sendiri atau dari sumber lain yang tidak terpantau oleh instansi resmi. Sertifikasi benih dan pengawasan mutu benih belum memadai baik sumberdaya manusia dan teknologinya. Kalaupun ada benih bermutu, harga jual benih kacang tanah masih dirasakan terlalu mahal oleh petani, sehingga petani cenderung menggunakan benih dari hasil seleksi pertanamannya sendiri, yang tidak jelas lagi generasinya (Purnomo dan Harnowo, 2015).

Petani kacang tanah di desa Kwangko selalu menggunakan benih asalan dari kultivar yang tidak diketahui lagi asal usulnya. Pemahaman tentang karakter varietas unggul kacang tanah yang mampu beradaptasi di lahan kering belum banyak dipahami oleh petani. Penggunaan varietas unggul merupakan anternatif untuk meningkatkan produktivitas kacang tanah di lahan kering. Berdasarkan uraian tersebut, maka kegiatan pengabdian kepada masyarakat ini telah dilakukan yang bertujuan untuk membantu kelompok tani mitra "Nanga Nae Dua" di Desa Kwangko untuk meningkatkan pengetahuan dan keterampilan petani dalam upaya meningkatkan produktivitas kacang tanah dengan penggunaan galur kacang tanah unggul (toleran kekeringan dan toleran naungan) dan produksi benih bermutu.

\section{METODE KEGIATAN}

Pemecahan masalah yang akan dilakukan pada program ini adalah melalui "penggunaan galur kacang tanah unggul dan produksi benih bermutu untuk meningkatkan produksi kacang tanah di lahan kering.

Untuk meningkatkan produksi kacang tanah diperlukan penerapan ilmu dan teknologi yang dimiliki oleh Tim Pengabdian Masyarakat. Teknologi peningkatan produksi kacang tanah dan produksi benih bermutu disampaikan pada kegiatan diseminasi (penyuluhan) dan demonstrasi plot. Tahapan kegiatan yang telah dilaksanakan meliputi :

\section{Persiapan}

a. Analisis kebutuhan. Kegiatan ini telah dilakukan dengan cara observasi, wawancara dan mengikuti kegiatan yang dilakukan oleh petani. Pengumpulan data antara lain meliputi problem utama yang dihadapi, keadaan masyarakat tani baik dilihat dari segi ekonomi, pendidikan maupun pandangannya terhadap suatu inovasi baru dan lain-lain.

b. Analisis penciptaan kegiatan yang produktif. Pengumpulan data dilakukan bersamaan dengan tahap kegiatan a) meliputi masalah sumberdaya hasil pertanian (potensi, produksi, dan lain-lain) yang berhubungan dengan penciptaan kegiatan usaha yang produktif dan pemilihan paket teknologi hasil pertanian yang akan dikembangkan. 
c. Sosialisasi program. Kegiatan ini bersifat pendekatan dan penyuluhan kepada masyarakat tentang manfaat dari kelanjutan program serta dampaknya terhadap tingkat pendapatan masyarakat.

d. Penentuan peserta. Peserta program yang terlibat dalam penyuluhan pengembangan galur kacang tanah unggul toleran kekeringan dan naungan dan produksi benih bermutu adalah 16 orang anggota dari kelompok petani.

2. Pelaksanaan program

a. Diseminasi. Pelaksanaan diseminasi dilakukan oleh tim penyuluh dengan menyampaikan informasi tentang pengembangan galur kacang tanah unggul toleran kekeringan dan naungan dan produksi benih bermutu. Metode yang digunakan dalam kegiatan diseminasi (penyuluhan) adalah metode pendidikan orang dewasa (POD) dengan teknik partisipatif. Materi penyuluhan disampaikan oleh Tim dan selanjutnya diikuti dengan diskusi dan tanya jawab. Materi penyuluhan meliputi kebijakan dan prospek usaha tani kacang tanah di NTB, produksi dan manfaat varietas/galur kacang tanah unggul, teknik budidaya kacang tanah untuk produksi kacang tanah di lahan kering (varietas unggul, benih unggul, pengapuran, pengolahan tanah, penanaman (jarak tanam), pembunbunan dan pengendalian hama/penyakit), pemanenan dan pasca panen, produksi benih berkualitas, dan benih bersertifikat.

b. Demonstrasi plot. Kgiatan ini dilakukan di lahan kering petani. Petani secara partisipatif ikut terlibat dari perencanaan, pelaksanaan dan evaluasi hasil panen.

Setelah melakukan diseminasi dan penyuluhan, kelompok tani mendapatkan praktek tentang penanaman varietas unggul kacang tanah dan memproduksi benih bermutu kacang tanah. Areal demplot dilakukan pada tanah petani seluas 10 are. Demontrasi plot dilaksanakan dengan membandingkan kebiasaan budidaya kacang tanah yang dilakukan oleh petani (menggunakan benih asalan) dan penggunaan galur kacang tanah unggul toleran kekeringan dan naungan. Tim pengabdian masyarakat dari Unram bersama-sama dengan kelompok petani menguji daya hasil beberapa galur kacang tanah di lahan kering. Galur-galur kacang tanah unggul yang digunakan berasal dari hasil penelitian Hemon et al. (2020).

Tim Pengusul telah memberikan pelayanan teknis kepada petani dengan mengundang partisipatif petani mulai dari penyusunan/perencanaan program, pelaksanaan kegiatan (aplikasi benih bermutu, menanam, memelihara, panen), membandingkan, dan memutuskan apakah program yang dilaksanakan memberi keuntungan atau tidak.

\section{HASIL DAN PEMBAHASAN}

Kegiatan pengabdian pada masyarakat telah melaksanakan dua kegiatan utama yaitu kegiatan diseminasi (penyuluhan) tentang penggunaan varietas unggul kacang tanah dan produksi benih bermutu serta demonstrasi plot penanaman galur kacang tanah unggul.

\section{Kegiatan Diseminasi (penyuluhan)}

Secara teoritis bahwa penyuluhan pertanian adalah upaya untuk mengubah perilaku petani agar memiliki pengetahuan yang lebih luas, memiliki sikap progresif untuk melakukan perubahaan dan inovatif terhadap sesuatu (informasi) baru serta terampil melaksanakan berbagai kegiatan yang bermanfaat bagi peningkatan produktivitas usaha pertanian, pendapatan/keuntungan, maupun untuk kesejahteraan keluarga dan masyarakat (Mardikanto, 1996).

Berdasarkan konsep ini, kegiatan pengabdian masyarakat ini telah dilakukan untuk meningkatkan pengetahuan petani tentang upaya meningkatkan produktivitas kacang tanah dengan penggunaan varietas/galur unggul kacang tanah yang toleran kekeringan dan naungan serta pengetahuan tentang produksi benih bermutu kacang tanah.

Hasil kegiatan pengabdian menunjukkan bahwa para peserta penyuluhan sangat respons terhadap kegiatan penyuluhan. Hal ini dapat dilihat dari kehadiran para peserta dan keterlibatan para peserta selama pelaksanaan penyuluhan. Kehadiran peserta sesuai dengan target yaitu sejumlah 16 orang 
dengan komposisi peserta yaitu anggota kelompok tani "Nanga Nae Dua", tokoh masyarakat, dan wanita tani. Peserta penyuluhan ini sengaja dipilih langsung dari kelompok tani, karena merekalah yang dianggap efektif yang langsung menerapkan informasi usaha tani kacang tanah. Kelompok tani ini telah biasa menanam kacang tanah di lahan kering namun hasil usaha tani yang mereka dapat selalu tidak optimum. Dilihat dari keterlibatan para peserta selama pelaksanaan penyuluhan, ternyata peserta sangat sungguh-sungguh mendengar dan terlibat secara langsung dalam tanya jawab (Gambar 1).

Kegiatan ceramah ini telah dilakukan untuk mengajarkan bagaimana peranan varietas unggul kacang tanah dan teknologi produksi benih berkualitas. Petani lebih antosias untuk mempraktekkan dengan melihat kenyataan yang ada di lapangan mulai dari penanaman sampai pemanenan. Teknik partisipatif terutama dilakukan untuk mendengar langsung permasalahan tentang produksi benih kacang tanah dan mengajak petani bersama-sama mencari solusi. Selain penjelasan dengan ceramah, penyampaian materi dilakukan dengan penyajian poster, untuk menjelaskan bagaimana memproduksi benih bermutu kacang tanah (Gambar 1).

Pada penyampaian materi poduksi benih bermutu, Tim penyuluh menyampaikan cara memproduksi benih agar diperoleh benih berkualitas yang sesuai dengan proses sertifikasi benih. Tahapan informasi yang telah disampaikan, yaitu:

- Ploting lahan penanaman, penanaman kultivar asalan, pemurnian benih dengan seleksi, pengaturan sampel tanaman dengan pembagian grid-grid lokasi tanaman, seleksi tanaman bisa lebih dari satu musim, benih hasil seleksi dibulk kembali, melakukan sortiran benih bernas (mutu fisik), pengepakan, dan penyimpanan.

Pada saat demplot dijelaskan juga tentang cara memproduksi benih kacang tanah agar diperoleh benih yang seragam dan murni. Seleksi massa adalah salah satu cara yang dilakukan pada kegiatan ini. Cara ini dilakukan berdasarkan kenampakan fenotipe tanaman, antara lain vigorous tanaman (keseragaman pertumbuhan), jumlah polong berisi dan berat kering polong. Tanaman yang teramati sebagai tipe simpang (off type) dicabut dan dibuang.
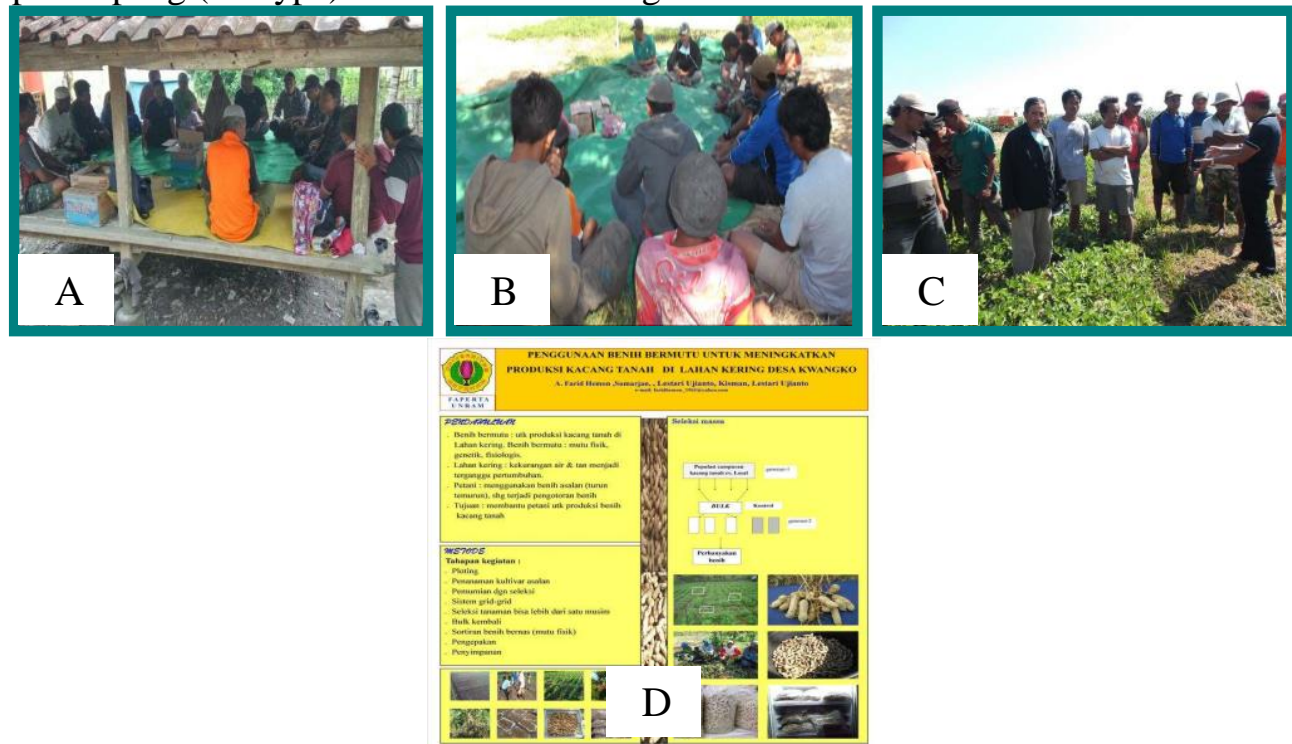

Gambar 1. Penyampaian materi penyuluhan. (A) \& (B) pemateri menyampaikan ceramah tentang penggunaan varietas unggul dan teknik produksi benih kacang tanah, (C). petani sedang serius mendengar penjelasan dan diskusi di lahan percobaan, dan (D) alat peraga poster untuk bahan penyampaian meteri penyuluhan

\section{$\underline{\text { Kegiatan Demonstrasi plot }}$}

Ilmu dan teknologi yang dihasilkan oleh peneliti perlu ditransfer ke petani. Akses petani terhadap informasi inovasi teknologi relatif terbatas sehingga diperlukan untuk sosialisasi dan memberikan pemahaman kepada petani. Pemahaman suatu inovasi teknologi tentu melalui suatu tahapan proses mental dari individu petani sampai mengambil keputusan untuk mengadopsinya Mardikanto (1993). 
Adopsi teknologi produksi benih tidak hanya cukup dilakukan melalui ceramah atau disikusi, namun perlu dilakukan melalui praktek langsung. Demontrasi plot adalah salah bentuk media penyuluhan yang dilakukan melalui praktek langsung di lapangan dengan membandingkan cara petani dan penerapan teknologi penggunaan varietas/galur unggul dan produksi benih.

Demonstrasi plot budidaya kacang tanah varietas unggul dan praktek produksi benih dilakukan di lahan petani. Petani secara partisipatif ikut terlibat secara bersama-sama dari perencanaan, pelaksanaan dan evaluasi hasil panen. Demonstrasi merupakan suatu metode penyuluhan di lapangan untuk memperlihatkan / membuktikan secara nyata tentang cara dan atau hasil penerapan teknologi pertanian yang telah terbukti menguntungkan bagi petani. Adopsi teknologi ini diharapkan akan terjadi perubahan perilaku baik yang berupa pengetahuan, sikap, maupun keterampilan petani setelah menerima "inovasi" yang disampaikan penyuluh kepada sasarannya. Penerimaan disini mengandung arti tidak sekedar "tahu" tetapi dengan benar-benar dapat dilaksanakan atau diterapkan dengan benar serta menghayatinya.

Pada kegiatan ini, setelah dilaksanakan penjelasan teoritis, maka dilanjutkan dengan penjelasan tentang Demplot. Penjelasan selanjutnya meliputi tentang pengolahan tanah, pembuatan plot, penanaman, pemeliharaan tanaman, dan pemanenan (Gambar 2).

Pada kegiatan demplot ini, Tim melakukan uji daya hasil dengan membandingkan antara galur kacang tanah unggul dengan benih asalah yang berasal dari petani. Penanaman dilakukan pada ukuran plot $2 \times 5 \mathrm{~m} 2$ dengan jarak tanam $40 \times 20 \mathrm{~cm} 2(40 \mathrm{~cm}$ jarak antar baris dan $20 \mathrm{~cm}$ jarak dalam baris).

Pada saat pemanenan, telah dijelaskan juga kriteria tanaman untuk dipanen, cara pemanenan, dan penanganan pasca panen sampai pengepakan benih. Pemanenan dilakukan pada umur 90 hari setelah tanam, dengan cara dicabut. Tanaman dapat dipanen apabila $>70 \%$ polong kacang tanah pada setiap tanaman telah masak secara fisiologis. Hal itu ditandai dengan warna lebih gelap pada permukaan kulit bagian dalam kacang tanah, kulit polong lebih mengeras, dan bagian daun telah mulai kuning dan gugur. Pada saat pemanenan juga diamati beberapa parameter seperti jumlah polong per tanaman, berat polong basah dan kering per plot. Pada Tabel 1 terlihat bahwa petani dapat secara langsung membandingkan hasil panen varietas unggul dengan benih asalan petani.

Tabel 1. Hasil demplot daya hasil beberapa galur kacang tanah yang dibandingkan dengan benih asalan dari petani (luas plot $2 \times 5 \mathrm{~m}^{2}$ )

\begin{tabular}{ccccc}
\hline Galur & $\begin{array}{c}\text { Jumlah polong } \\
\text { per tanaman }\end{array}$ & $\begin{array}{c}\text { Berat polong segar } \\
\text { per plot }(\mathrm{g})\end{array}$ & $\begin{array}{c}\text { Berat polong } \\
\text { kering } \\
\text { per plot }(\mathrm{g})\end{array}$ & $\begin{array}{c}\text { Berat polong } \\
\text { kering } \\
\text { (ton.ha }\end{array}$ \\
\hline G200-I & $20,67 \mathrm{a}$ & $4645,3 \mathrm{a}$ & $2767,5 \mathrm{a} *)$ & 2,8 \\
G300-II & $20,53 \mathrm{a}$ & $5687,5 \mathrm{a}$ & $3245,6 \mathrm{a}$ & 3,3 \\
G3T10 & $16,20 \mathrm{ab}$ & $4356,7 \mathrm{a}$ & $2634,5 \mathrm{a}$ & 2,6 \\
G7-UIII & $18,00 \mathrm{a}$ & $4232,8 \mathrm{a}$ & $2534,3 \mathrm{ab}$ & 2,5 \\
G14-UI & $17,65 \mathrm{a}$ & $4215,6 \mathrm{a}$ & $2513,6 \mathrm{ab}$ & 2,5 \\
Benih asalan & $10,50 \mathrm{~b}$ & $2475,5 \mathrm{~b}$ & $1305,6 \mathrm{~b}$ & 1,3 \\
petani & & & &
\end{tabular}

${ }^{*}$ Angka yg diikuti oleh huruf yang sama pada kolom yg sama tidak berbeda nyata pada uji Duncan 5\%
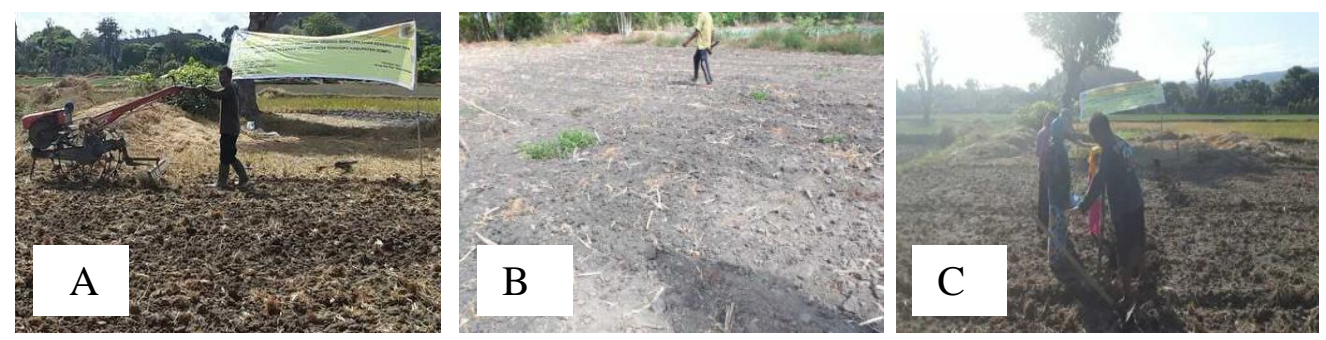

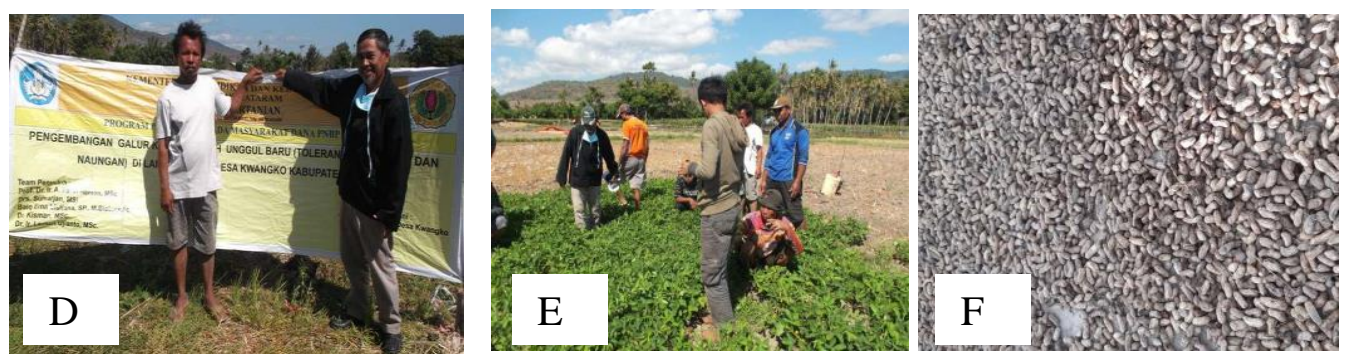

Gambar 2. Tahapan demplot uji daya hasil beberapa galur kacang tanah di lahan kering. (A) pengolahan tanah, (B) hamparan lahan kering siap untuk ditanam dengan kacang tanah, (C) penanaman beberapa galur kacang tanah, (D) pose ketua kelompok tani dengan Tim Unram, (E) penjelasan lapangan oleh Tim Unram tentang pertumbuhan kacang tanah, dan (E) penjemuran hasil panen benih kacang tanah

\section{Kesimpulan}

\section{KESIMPULAN DAN SARAN}

Hasil kegiatan menunjukkan bahwa petani sangat respon terhadap kegiatan pengembangan galur kacang tanah unggul toleran kekeringan dan naungan. Proses transformasi teknologi penggunaan varietas unggul dan produksi benih berkualitas kacang tanah telah terjadi pada petani. Petani juga mampu menggunakan benih bermutu untuk budidaya kacang tanah di lahan kering Desa Kwangko. Petani dapat membandingkan hasil demonstrasi plot antara benih dari galur unggul dengan benih asalan dari petani. Penggunaan galur unggul kacang tanah dari benih bermutu mampu meningkatkan produksi kacang tanah 2,5 - 3,3 ton ha-1polong kering atau meningkat sebesar 48-60,6\% dibanding dari benih asalan petani (1,3 ton ha-1) polong kering.

\section{Saran}

Untuk meningkatkan produktivitas kacang tanah di lahan kering harus menggunakan varietas unggul dari benih bermutu. Varietas unggul kacang tanah dapat diperoleh dari Balitkabi Malang. Produksi benih bermutu dapat dilakukan oleh petani sendiri dengan bantuan para penyuluh atau mahasiswa KKN dari Fakultas Pertanian Unram.

\section{UCAPAN TERIMA KASIH}

Kegiatan pengabdian kepada masyarakat ini terlaksana atas dukungan biaya dari DIPA BLU UNRAM tahun Anggaran 2020.

\section{DAFTAR PUSTAKA}

Adisarwanto, T., 2008. Meningkatkan Produksi Kacang Tanah di Lahan Sawah dan Lahan Kering. Penebar Swadaya. Jakarta. H 26.

BPS Kabupaten Dompu, 2018. Kecamatan Manggelewa dalam Angka. Badan Pusat Statistik Kabupaten Dompu.

Hemon, A.F, Sumarjan, Hanafi, A., 2018-2019. Perbaikan Karakter Tanaman Kacang Tanah : Toleran Naungan dan Berdaya Hasil Tinggi (>3,0 ton polong kering per hektar) di Lahan Kering. Penelitian Unggulan Terapan Perguruan Tinggi, Universitas Mataram.

Hidajat JR, Kartaatmadja S, Rais SA. 1999. Teknik produksi benih kacang Tanah. Pusat Penelitian dan Pengembangan Tanaman Pangan, Badan Penelitian dan Pengembangan Pertanian. Jakarta.

Mardikanto, T. 1993. Penyuluhan Pembangunan Pertanian. (Cetakan Kedua). Penerbit Sebelas Maret University Press. Surakarta.

Purnomo, J dan Harnowo, D. 2015. Teknologi produksi benih sumber kacang tanah. Balai Penelitian Tanaman Aneka Kacang dan Umbi. http://balitkabi.litbang. pertanian.go.id/wpcontent/uploads/2015/06/21._OK_JokoP_407-426-1.pdf. 